\title{
The Morphosyntactic Abilities of Bilingual Malay Preschool Children Based on the Malay and English Sentence Repetition Tasks
}

\author{
Zur Hanis Hamim ${ }^{1}$, Rogayah Abdul Razak ${ }^{2 *}$ and Badrulzaman Abdul Hamid ${ }^{1}$ \\ ${ }^{1}$ Speech Science Program, Centre for Rehabilitation and Special Needs Studies, Faculty of Health Science, \\ Universiti Kebangsaan Malaysia, 50300, Kuala Lumpur, Malaysia \\ ${ }^{2}$ Dept of Postgraduate Studies, Faculty of Education, Language and Psychology, SEGI University, 47810, \\ Selangor, Malaysia
}

\begin{abstract}
Sentence repetition task has been proven to be a tool that can detect language difficulties and is indicative of abnormal language. In Malaysia, studies on the language abilities of bilingual children in sentence repetition (SR) tasks are sparse. Therefore, this study is aimed at examining the morphosyntactic abilities of 60 bilingual Malay children aged 4;0 to $6 ; 11$ based on SR tasks in Malay (L1) and English (L2). In the SR task, participants were asked to listen carefully to sentences being read out and then repeat verbatim the sentences heard. Their responses were scored based on accuracy, syntax, grammar, and word categories. The findings demonstrated a significant difference between the two languages in terms of accuracy $[\mathrm{df}=118, \mathrm{t}=1.990, \mathrm{p}=.049]$; the Malay language had statistically higher scores compared to English scores. There was also a significant difference on the performance based on age factor, [Malay $\left(\mathrm{df}_{5,54}=3.561, \mathrm{p}=.007\right)$; English $\left(\mathrm{df}_{5,54}=2.894\right.$, $\mathrm{p}=.022)]$. The results also revealed that the omission of both content and function words was more prominent compared to other error types. A triangulation of the quantitative and qualitative data was done. The findings highlighted the morphosyntactic abilities of the bilingual children in both languages and error patterns produced.
\end{abstract}

Keywords: Bilingualism, morphosyntax abilities, second-language acquisition, sentence repetition task

ARTICLE INFO

Article history:

Received: 10 August 2020

Accepted: 13 February 2021

Published: 26 March 2021

DOI: https://doi.org/10.47836/pjssh.29.1.04

$\overline{\text { E-mail addresses: }}$

zurr.hanis@gmail.com (Zur Hanis Hamim)

rogayah@segi.edu.my (Rogayah A. Razak)

badrulhamid@ukm.edu.my (Badrulzaman Abd Hamid)

* Corresponding author

\section{INTRODUCTION}

In Malaysia, most speakers are multilingual or at least bilingual. However, multilingualism in Malaysia is unique as the mixture of existing languages is based on the status of the languages. Standard languages and their colloquial varieties are used inextricably, and this code mixing presents unique 
challenges in the management of bilingual children at risk of language problems.

Studies on bilingual children are often beset by the dichotomy of standard versus colloquial varieties. Uneven distribution of abilities in a child's languages, crosslinguistic associations within bilinguals, and individual variations also posed challenges in the diagnosis and treatment of language impairment (Kohnert, 2010). These developmental differences may lower the accuracy scores in imported language assessment tools and make a bilingual child's language appears disordered when compared to a monolingual counterpart (Paradis, 2009, 2010). On top of that, the lack of locally developed bilingual language assessment tools has hampered successful identification of bilinguals with developmental language difficulties (Woon, 2012), of which it is said affects about $7 \%$ of the world population (Tomblin et al., 1997). A child's score on a standardised test poses the question as to whether it represents limited exposure to the second language or is it more of a developmental deficit. If it is the latter, evidence of language impairment must be apparent across both L1 and L2. The risk of under- or over-diagnosis, therefore, can be minimized by tests such as sentence repetition (SR) task which has been proven to be highly sensitive to differentiate language delay due to bilingualism rather from language impairment (Komeili \& Marshall, 2013).

SR task has been widely used as a tool to measure children's language abilities, particularly their morphosyntactic knowledge (Kaltsa et al., 2019). The high diagnostic accuracy, specificity, and sensitivity of SR have made the task to be a reliable measure of language impairment (Conti-Ramsden et al., 2001; Leclercq et al., 2014; Marinis \& Armon-Lotem, 2015; Orlovska \& Rascevska, 2014; Riches, 2012; Riches et al., 2010; Seeff-Gabriel et al., 2010; Stokes et al., 2006; Thordardottir \& Brandeker, 2013; Thordardottir et al., 2011). However, not much has been reported on bilingual SR tasks to test bilingual children in Malaysia. In this study, we are going to investigate the language abilities of bilingual Malay children speaking MalayEnglish in the respective SR tasks, i.e., the English SR and Malay SR. The SR tasks could subsequently be a reliable tool to identify bilingual Malay children speaking Malay and English who might be at risk of language impairment.

\section{Bilingualism}

Bilingualism can be acquired either simultaneously during childhood or learnt successively either during childhood or adulthood. Although bilingual children's language milestones are believed to be the same as monolingual children (Brojde et al., 2012), their receptive and expressive language skills may vary. This may be due to factors such as language dominance, language exposure, and language input which can also contribute to a delay in language development (Hoff \& Core, 2013; Hoff et al., 2012). As bilingual speakers typically possess stronger and weaker languages within their language repertoire, 
they would use the more dominant language more often than the other with better proficiency, greater vocabulary, longer sentences, and fewer pauses (Montrul, 2009).

Although balanced proficiency would be possible, the attainment of L2 can vary across individuals. A study on Hmong natives in the USA found that children who were exposed to Hmong and English at preschool for at least 16 months showed significant improvement on pictureidentification and naming task in English, as compared to the younger group who had only attended preschool for 9 months (Kan $\&$ Kohnert, 2005). However, no evidence of significant changes was found in L1 (Hmong) based on each task across both groups. The more enriching class experience with L2 (English) through instructions by teachers and therapists had facilitated English development more significantly than Hmong which was only used in transitions between classrooms.

The findings of relatively stable development of L2 - as opposed to increasing skills in L1 - stand in contrast to the more recent study of Gatt and Dodd (2019). Their study revealed that children at 3-4 years old at preschool-entry level showed consistent growth in their receptive and expressive lexical abilities in their L1 (Maltese) but limited improvement in L2 (English), despite significant exposure of the L2 in preschool. Notice that, in the studies mentioned, discrepancies in lexical trajectories were still detected despite similar time length of language contact. Such findings implied (a) that systematic bilingual education was insufficient to maintain the sequential bilingual development of the L2, and (b) that other factors such as different language pairs, their typological distance, and their L1/L2 status could be more impactful for the development of bilingual language.

\section{Sentence Repetition Task as a Measure of Morphosyntactic Abilities of Bilingual Children}

Polišenská et al. (2015) claimed that SR was capable of measuring working memory, language abilities or the relationship between these two aspects. SR involves construction of gradual complexities in the form of syntactic structure and vocabulary relative to age, memory capacity, and language abilities of the child to proportionally draw from their grammatical system. Several studies (Montgomery et al., 2010; Riches et al., 2010; Willis \& Gathercole, 2001) suggest that the task necessarily taps on the syntactic knowledge stored in the longterm memory (LTM) to repeat the sentence input, besides depending on the shortterm memory (STM) and other cognitive processes including phonological short-term memory (PSTM) and working memory. It is hypothesised that participants would analyse a sentence at the phonological, morphosyntactic, and semantic levels and use the production system to regenerate the meaning of the sentence from activated representations in LTM in carrying out this task. Relatively long and complex sentences used in the SR task will make it possible to 
investigate the areas of morphosyntax and lexical phonology based on the assumption that children will be able to repeat the sentences had they acquired the relevant syntax knowledge (Polišenská et al., 2015; Theodorou et al., 2017). In the SR task, sentence length and vocabulary are kept consistent to ensure that the children's memory will not be disproportionately affected in any structures or languages (Marinis \& Armon-Lotem, 2015). So far, SR has been used by studies in numerous languages including Cantonese (Stokes et al., 2006), Italian (Vicari et al., 2002), and Mandarin (Woon et al., 2014).

In recent years, SR task has garnered much attention for its ability to determine the difference between typical and atypical development in bilingual population. A pocket of systematic grammatical errors such as the omission of grammatical morphemes, the modification of word order, and the substitution of vocabulary were found across bilinguals. In line with these findings, it is suggested that children with different language profiles make different types of errors (Meir et al., 2015). While children of typical language development would typically repeat content and function words and inflections with equal accuracy, children with language impairment were reported to repeat function words and inflections less accurately than content words, with the most common error being omission (Komeili \& Marshall, 2013). In a recent study by Kaltsa et al. (2019), it was reported that (a) Greek monolinguals outperformed Albanian-Greek sequential and simultaneous bilinguals in
SR, and (b) vocabulary and syntactic skills were closely related for simultaneous but not for sequential bilinguals.

While SR has been extensively used to determine language abilities of bilingual children around the world, limited research has been done on the language development of bilingual Malaysian children for speech language therapy (SLT) purposes apart from the studies done by Woon (2012) and Ooi and Wong (2012). Woon (2012) reported that the bilingual Mandarin-English children showed better performance in the Mandarin SR task than the English SR, thus reflecting their developmental stages of the lexical and morphosyntactic knowledge. Unlike younger children, most 5- and 6-year-old children were found to have acquired most of the selected classifiers, aspect markers and complex structures featured in the study. Interestingly, errors produced in the English SR task were also common errors found in an adult's grammar. Meanwhile, Ooi and Wong (2012) observed that the Chinese children's omission of verbs, prepositions, and copula- BE was likely to be seen in children with language impairment than typically developing children and that it could be attributed to the influence of the L1 (Chinese) because preposition and copulaBE were optional in Chinese.

This study aims to investigate the morphosyntactic abilities of typically developing bilingual Malay preschool children in two languages that they use Malay and English - based on a bilingual sentence repetition task. The following objectives are addressed in the study: (i) 
to determine the performance in terms of the morphological and syntactic abilities of the bilingual children based on the SR task, (ii) to examine the influence of the two languages - Malay and English - on the children's performance, and (iii) to identify error patterns produced in the SR task. It is hypothesized that (a) there would be two factors, i.e., age and language which would significantly affect the performance of the bilingual Malay children on the two SRs, and (b) Malay bilingual children would perform better in their L1 (Malay) compared to their L2 (English).

\section{METHOD}

\section{Participants}

Purposive sampling method was used to select participants for this study. The SR tasks were administered to 60 bilingual preschool children of Malay ethnicity aged 4;0-6;11 years old around Klang Valley. These children spoke Malay as their L1 and learnt English as their L2 when they entered kindergarten. $70 \%$ of them had spent at least one year in Englishmedium preschools. The children were also reported by teachers, parents, or caregivers to have demonstrated typical executive functioning abilities in their physical, cognitive, social, and behavioral domains. Potential participants who were reported by parents, teachers or caregivers as having a history of communication difficulties were excluded from the study. Table 1 presents the demographic profiles of participants.

\section{Materials}

The SR tasks consist of two sections, namely, a) Section A: Multilingual Sentence Imitation Task (Multi-SIT) (adapted from Marinis et al., 2012) to suit Standard Malaysian English variety and b) Section B: Aktiviti Pengulangan Ayat dalam Bahasa Malaysia/Malay SR (an adaptation from Abu Bakar, 2017). Each task in the respective language was amended to control for the same number of morphosyntactic targets, resulting in 24 counter-balanced sentence items. A few original structures were omitted as it was found to be inappropriate

Table 1

Demographic profiles of participants according to age groups

\begin{tabular}{lcccccc}
\hline $\begin{array}{c}\text { Age } \\
\text { range } \\
(\mathrm{y} ; \mathrm{m})\end{array}$ & $\begin{array}{c}\text { Mean } \\
\text { age } \\
(\mathrm{y} ; \mathrm{m})\end{array}$ & $\begin{array}{c}\text { No. of } \\
\text { male } \\
\text { participants }\end{array}$ & $\begin{array}{c}\text { No. of } \\
\text { female } \\
\text { participants }\end{array}$ & $\begin{array}{c}\text { Total number } \\
\text { of participants }\end{array}$ & $\begin{array}{c}\text { No. of children } \\
\text { attending } \\
\text { public preschools }\end{array}$ & $\begin{array}{c}\text { No. of children } \\
\text { attending private } \\
\text { preschools }\end{array}$ \\
\hline $4 ; 0-4 ; 5$ & $4 ; 02$ & 4 & 6 & 10 & 3 & 7 \\
$4 ; 6-4 ; 11$ & $4 ; 08$ & 5 & 5 & 10 & 1 & 9 \\
$5 ; 0-5 ; 5$ & $5 ; 01$ & 4 & 6 & 10 & 0 & 10 \\
$5 ; 6-5 ; 11$ & $5 ; 08$ & 5 & 5 & 10 & 2 & 8 \\
$6 ; 0-6 ; 5$ & $6 ; 01$ & 4 & 6 & 10 & 0 & 10 \\
$6 ; 6-6 ; 11$ & $6 ; 08$ & 6 & 4 & 10 & 3 & 7 \\
\hline Total & & 28 & 32 & 60 & 9 & 51 \\
\hline
\end{tabular}

Note. (y;m), years; months 
from the aspects of sociolinguistics for the target population. Both lists are made up of the following structures: a) SVO+AUX/ MODAL (4), (b) Negation SVOA (1), (c) Wh-question (3), (d) Passives (4), (e) Complement sentence (Malay 3; English 2),

(f) Compound sentence (2) (g) Subordinate sentence (Malay 1; English; 2), (h) Objectrelative clauses (2), (i) Subject-relative clause (2), and (j) Cleft sentence (2).

\section{Procedures (SR protocol)}

The study was conducted using the procedure of the LITMUS SR protocols as outlined in Marinis and Armon-Lotem (2015). Two practice items were given in the Malay and English SR respectively, before the start of each task. During testing, each participant was instructed to listen carefully to the audio recording of sentences via a headset and then was asked to repeat verbatim the sentences heard. The scoring method was based on COST Action IS0804. Responses for SR tasks were scored based on four components, namely accuracy (overall), grammaticality, sentence type, and types of errors. For accuracy, score 1 was given if the sentence was correctly repeated (allowances may be given), and score 0 if there were errors. Meanwhile, for grammaticality, score 1 was given if the sentence had no grammatical errors, regardless of whether it matched the target sentence, and score 0 if the sentence was ungrammatical. As for sentence type, score 0 was given if the child did not produce the targeted structure, e.g., if the child produced a subject relative clause instead of an object relative clause or an active sentence instead of a passive sentence. The maximum overall score is 24. Ample time was given for the child to respond, and their inputs were scored and coded in the scoring sheet. A qualitative analysis was conducted to provide an indepth analysis of the errors produced by the participants. The error categories employed were a) omission, b) substitution, or c) addition of content and function words.

\section{RESULTS}

\section{Accuracy, Grammaticality and Sentence Type Scores}

The means and standard deviations for each group on the overall performance of the bilingual preschool Malay children are presented in Table 2. Generally, the mean scores in both languages across the age groups increased with the increase in age.

One-way ANOVA revealed significant mean differences between the 6 age groups in both languages based on age factor: MSR [df $\left._{5,54}=7.091, \mathrm{p}<.05\right]$; ESR [ $\mathrm{df}_{5,54}=5.021$, $\mathrm{p}<.05]$. Based on English SR post-hoc comparison, three age group categories; $5 ; 6$ $5 ; 11,6 ; 0-6 ; 5$ and 6;6-6;11 are significantly higher than the age group of $4 ; 0-4 ; 5$. The mean scores of $5 ; 6-5 ; 11,6 ; 0-6 ; 5$ and $6 ; 6-$ $6 ; 11$ groups are reported at $(11.0 \pm 5.676)$, (14.6 \pm 5.232$)$ and (17.6 \pm 3.502$)$ respectively; meanwhile, the mean score of the age group $4 ; 0-4 ; 5$ is reported at (7.3 \pm 6.273$)$. Further Malay SR post-hoc comparisons revealed that two age group categories $6 ; 0-6 ; 5$ and 6;6-6;11 are significantly higher than the age groups of $4 ; 0-4 ; 5$ and $4 ; 6-4 ; 11$. The mean scores of $6 ; 0-6 ; 5$ and $6 ; 6-6 ; 11$ 
Table 2

Descriptive statistics of the accuracy scores in the SR tasks according to age group

\begin{tabular}{lccccc}
\hline \multirow{2}{*}{ Age group $(\mathrm{y} ; \mathrm{m})$} & \multicolumn{2}{c}{ Malay SR } & \multicolumn{2}{c}{ English SR } \\
\cline { 2 - 5 } & $\mathrm{N}$ & Mean & SD & Mean & SD \\
\hline $4 ; 0-4 ; 5$ & 10 & 9.5 & 4.696 & 7.3 & 6.273 \\
$4 ; 6-4 ; 11$ & 10 & 10.4 & 3.406 & 6.8 & 4.050 \\
$5 ; 0-5 ; 5$ & 10 & 14.2 & 2.658 & 11.0 & 4.422 \\
$5 ; 6-5 ; 11$ & 10 & 15.1 & 4.408 & 11.0 & 5.676 \\
$6 ; 0-6 ; 5$ & 10 & 15.4 & 3.864 & 14.6 & 5.232 \\
$6 ; 6-6 ; 11$ & 10 & 15.4 & 3.204 & 17.6 & 3.502 \\
Total & 60 & 13.13 & 4.367 & 11.38 & 6.098 \\
\hline
\end{tabular}

$\mathrm{DF}=5,54$

Note. $(\mathrm{y} ; \mathrm{m})$, years; months

Table 3

Correlations between accuracy, grammaticality, and sentence type scores

\begin{tabular}{lllcc}
\hline & & Grammaticality & Sentence type \\
\hline Malay SR & Accuracy & Correlation & 0.878 & -0.857 \\
& & Significance (2-tailed) & 0.122 & 0.143 \\
\multirow{2}{*}{ English SR } & \multirow{2}{*}{ Accuracy } & Correlation & 0.723 & -0.588 \\
& & Significance (2-tailed) & 0.277 & 0.412 \\
\hline
\end{tabular}

groups are reported at $15.4 \pm 3.864$ and $15.4 \pm 3.204$, while the mean scores for $4 ; 0$ $4 ; 5$ and $4 ; 6-4 ; 11$ groups are at $9.5 \pm 4.696$ and $10.4 \pm 3.406$, respectively. There was also a significant difference between the two languages in terms of accuracy $[\mathrm{df}=118$, $\mathrm{t}=1.990, \mathrm{p}=.049]$. Statistically, Malay had a higher score $(13.13+4.28)$ compared to English $(11.38+6.11)$.

Table 3 presents the correlations between the three components of SR tasks. Correlation analyses showed that, despite the negative correlation observed between SR accuracy and sentence type scores, the accuracy scores and grammaticality scores in Malay and English languages showed positive correlation. This supports the notion a) that grammatical knowledge is important to ensure the accuracy in SR task and b) that, despite the accurate performance on the content and functions words in the sentences, the syntactic structure of those sentences repeated may not match the targeted sentence type.

\section{Morphosyntactic Analyses of Bilingual SR Task}

Morphological performance in SR tasks was determined based on the number of content and function words used in each sentence stimuli. Content words in both tasks comprised nouns, verbs, adjectives, and adverbs (refer Figure 1). Function words in the ESR included articles, copula-BE, determiners, conjunctions, prepositions, pronouns, auxiliary verbs, 
modals, and question words. Meanwhile, function words in the Malay SR included article, conjunctions, prepositions, pronouns, question words, auxiliary verbs, and negation. Since the bilingual SR is constituted from differing numbers of content and function words, the mean numbers of content and function words repeated correctly by each group were converted to percentage scores and tabulated as seen in Table 4.
Furthermore, a two-way ANOVA test was conducted to identify the interaction between language as the within-subject variable and age factor as the betweensubject variable on each word category in the performance of bilingual children in this study. Simple main effects in the production of content word showed that there was a significant interaction between the effects of age groups and language on the production of content words, $\mathrm{F}(11,108)$

Table 4

Group performances on word categories in Malay SR and English SR

\begin{tabular}{lcccc}
\hline \multirow{2}{*}{$\begin{array}{l}\text { Age group } \\
(\mathrm{y} ; \mathrm{m})\end{array}$} & \multicolumn{2}{c}{ Malay SR (\%) } & \multicolumn{2}{c}{ English SR (\%) } \\
\cline { 2 - 5 } & $\mathrm{CW}$ & $\mathrm{FW}$ & 66.40 & $\mathrm{FW}$ \\
\hline $4 ; 0-4 ; 5$ & 63.60 & 35.60 & 55.10 & 50.80 \\
$4 ; 6-4 ; 11$ & 61.30 & 39.20 & 83.90 & 37.90 \\
$5 ; 0-5 ; 5$ & 69.70 & 45.80 & 68.20 & 76.90 \\
$5 ; 6-5 ; 11$ & 50.70 & 86.50 & 49.30 \\
$6 ; 0-6 ; 5$ & 74.20 & 62.0 & 88.40 & 71.70 \\
$6 ; 6-6 ; 11$ & 77.0 & 59.30 & & 75.90 \\
\hline
\end{tabular}

Notes. CW, content word; FW, function word; (y;m), years; months

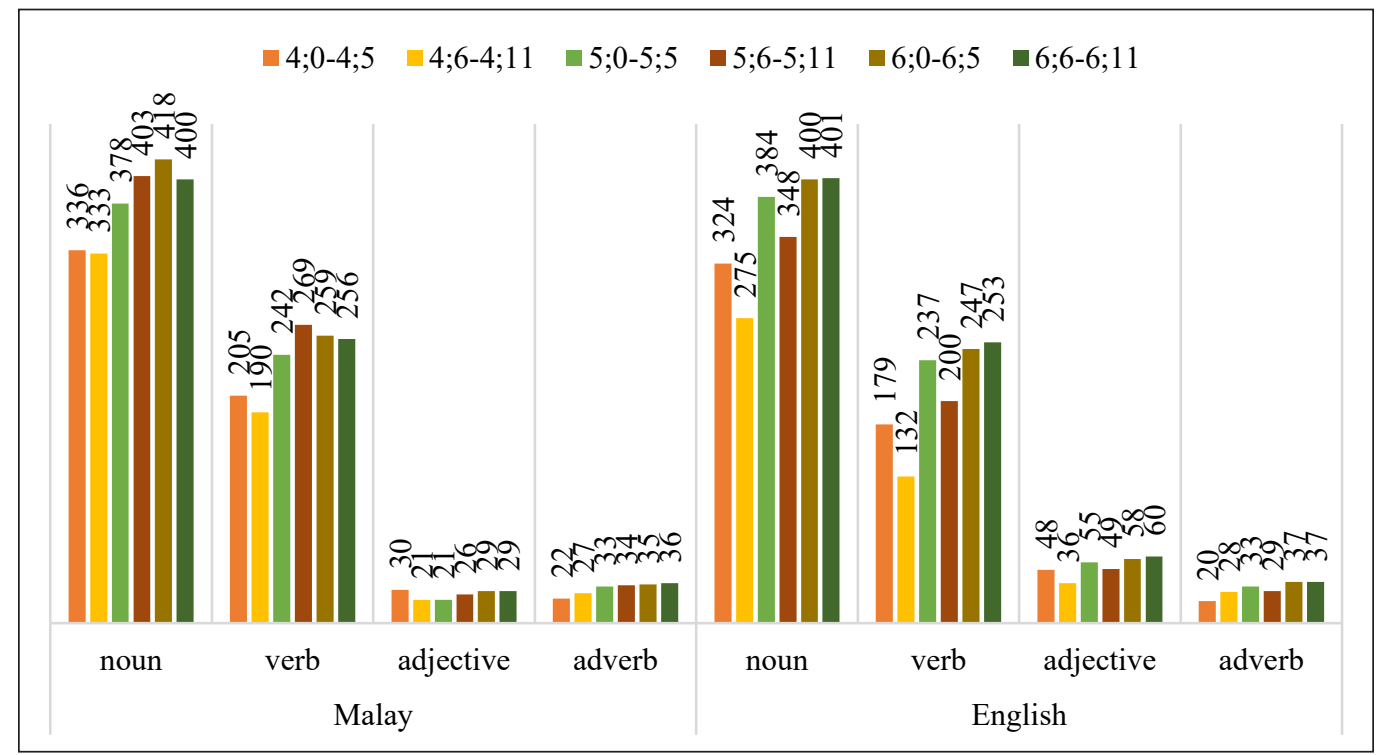

Figure 1. Frequency of content word distributions based on age groups and language 
$=2.338, \mathrm{p}=.047$. The analysis revealed a statistically significant main effect of age groups, $\mathrm{F}(11,108)=8.932, \mathrm{p}=.000$ but not-statistically significant main effect of language type $\mathrm{F}(11,108)=0.366, \mathrm{p}=.546$. As for the production of function words, no interaction was found between the two variables, $\mathrm{F}(11,108)=2.252, \mathrm{p}=.054$. Again, the analysis revealed a statistically significant main effect of age groups, $F(11$, $108)=8.526, p=.000$ and significant main effect of language type $\mathrm{F}(11,108)=117.469$, $\mathrm{p}=.000$. All significant pair comparisons based on Bonferroni post-hoc test between age groups at both word categories with their $p$ values are presented in Table 5 and Table 6.

\section{Error Patterns}

This study examined the error patterns produced by the participants in all age groups specifically comparing function word and content word errors within the thematic error types. In Table 7 and Table 8 , the data presents reversal patterns upon the three types of errors. There was a steady decrease in the mean of omission errors and a steady increase in the mean of substitution and addition errors as the age increased. Overall, omission error was more prominent compared to other error types.

In Table 9, we present examples of morphological and syntactic errors in the repetition of the sentences in English. The asterisk symbol * indicates an ungrammatical production of the sentence. As can be seen from the examples in Table 9, not all errors resulted in ungrammatical response as some sentences still adhered to the correct word order.

In Table 10, we present the example of morphological and syntactic errors in Malay. The relative clause (RC) marker 'yang' (that) is not yet used or deleted by participants as this is a structure which is acquired later beyond the preschool years.

Table 5

Age pair comparisons (significant p values only) based on content word

\begin{tabular}{|c|c|c|c|c|c|c|}
\hline Age group $(y ; m)$ & $4 ; 0-4 ; 5$ & $4 ; 6-4 ; 11$ & $5 ; 0-5 ; 5$ & $5 ; 6-5 ; 11$ & $6 ; 0-6 ; 5$ & $6 ; 6-6 ; 11$ \\
\hline $4 ; 0-4 ; 5$ & & & & & .003 & .011 \\
\hline $4 ; 6-4 ; 11$ & & & .001 & .045 & .000 & .000 \\
\hline
\end{tabular}

*The mean difference is significant at the .05 level.

Note. $(\mathrm{y} ; \mathrm{m})$, years; months

Table 6

Age pair comparisons (significant p values only) based on function word

\begin{tabular}{|c|c|c|c|c|c|c|}
\hline Age group $(\mathrm{y} ; \mathrm{m})$ & $4 ; 0-4 ; 5$ & $4 ; 6-4 ; 11$ & $5 ; 0-5 ; 5$ & $5 ; 6-5 ; 11$ & $6 ; 0-6 ; 5$ & $6 ; 6-6 ; 11$ \\
\hline $4 ; 0-4 ; 5$ & & & & & .004 & .002 \\
\hline $4 ; 6-4 ; 11$ & & & & & .000 & .000 \\
\hline $5 ; 6-5 ; 11$ & & & & & .048 & .02 \\
\hline
\end{tabular}

*The mean difference is significant at the .05 level.

Keynote. (y;m), years; months 
Table 7

Mean (SD) of types of errors in Malay SR

\begin{tabular}{lcccccc}
\hline \multirow{2}{*}{$\begin{array}{l}\text { Age group } \\
(\mathrm{y} ; \mathrm{m})\end{array}$} & \multicolumn{2}{c}{ Omission } & \multicolumn{2}{c}{ Substitution } & \multicolumn{2}{c}{ Addition } \\
\cline { 2 - 6 } & $\mathrm{CW}$ & $\mathrm{FW}$ & $\mathrm{CW}$ & $\mathrm{FW}$ & $\mathrm{CW}$ & $\mathrm{FW}$ \\
\hline $4 ; 0-4 ; 5$ & $31.2(10.87)$ & $36.6(12.51)$ & $1.5(1.51)$ & $0.9(1.3)$ & $0.5(0.53)$ & $0.1(0.32)$ \\
$4 ; 6-4 ; 11$ & $32.6(10.9)$ & $32.2(9.89)$ & $1.7(1.16)$ & $3.1(2.33)$ & $0.7(0.68)$ & $1.4(1.17)$ \\
$5 ; 0-5 ; 5$ & $22.5(7.32)$ & $27.3(4.14)$ & $1.8(1.48)$ & $1.3(1.34)$ & $1.0(1.05)$ & $0.8(1.03)$ \\
$5 ; 6-5 ; 11$ & $19.5(10.24)$ & $22.9(8.69)$ & $2.4(1.51)$ & $1.6(1.27)$ & $2.0(2.58)$ & $2.9(1.66)$ \\
$6 ; 0-6 ; 5$ & $18.3(10.14)$ & $19.3(1.87)$ & $2.2(1.42)$ & $1.7(1.42)$ & $0.6(0.84)$ & $1.7(1.16)$ \\
$6 ; 6-6 ; 11$ & $19.6(8.04)$ & $19.7(7.92)$ & $3.9(3.25)$ & $2.0(2.26)$ & $0.9(0.87)$ & $2.2(1.03)$ \\
Total & $23.95(9.59)$ & $26.33(7.50)$ & $2.25(1.72)$ & $1.76(1.65)$ & $0.95(1.09)$ & $1.51(1.06)$ \\
\hline
\end{tabular}

Keynotes. SD, standard deviation; CW, content word; FW, function word; (y;m), years; months

Table 8

Mean (SD) of types of errors in English SR

\begin{tabular}{lcccccc}
\hline \multirow{2}{*}{$\begin{array}{l}\text { Age group } \\
(\mathrm{y} ; \mathrm{m})\end{array}$} & \multicolumn{2}{c}{ Omission } & \multicolumn{2}{c}{ Substitution } & \multicolumn{2}{c}{ Addition } \\
\cline { 2 - 6 } & $\mathrm{CW}$ & $\mathrm{FW}$ & $\mathrm{CW}$ & $\mathrm{FW}$ & $\mathrm{CW}$ & $\mathrm{FW}$ \\
\hline $4 ; 0-4 ; 5$ & $26.2(17.15)$ & $48.3(27.37)$ & $1.2(1.81)$ & $1.7(2.45)$ & $0.5(0.53)$ & $1(1.56)$ \\
$4 ; 6-4 ; 11$ & $36.8(18.04)$ & $63.8(21.3)$ & $0.8(1.55)$ & $1.0(1.41)$ & $0.2(0.42)$ & $0.8(1.14)$ \\
$5 ; 0-5 ; 5$ & $11.3(6.84)$ & $35.2(16.1)$ & $1.1(0.74)$ & $4.9(3.51)$ & $0.5(0.71)$ & $2.7(2.16)$ \\
$5 ; 6-5 ; 11$ & $24.9(19.96)$ & $49.2(24.85)$ & $1.2(1.62)$ & $2.6(2.50)$ & $0.7(1.06)$ & $1.7(1.83)$ \\
$6 ; 0-6 ; 5$ & $8.9(8.56)$ & $19.4(15.39)$ & $1.7(2.06)$ & $8.2(4.47)$ & $0.4(0.52)$ & $2.8(1.93)$ \\
$6 ; 6-6 ; 11$ & $8.3(8.63)$ & $17.5(13.34)$ & $1.5(1.08)$ & $6.3(3.89)$ & $0.5(0.85)$ & $3.1(3.11)$ \\
\hline Total & $19.4(13.19)$ & $38.9(19.73)$ & $1.25(1.47)$ & $4.11(3.04)$ & $0.46(0.68)$ & $2.01(1.96)$ \\
\hline
\end{tabular}

Keynotes. SD, standard deviation; CW, content word; FW, function word; (y;m), years; months

Table 9

Examples of English sentence repetitions scored based on grammaticality

\begin{tabular}{|c|c|c|c|}
\hline Morphological error & Sentence type & Target sentence & Participants' response \\
\hline $\begin{array}{l}\text { Omission of -ed } \\
\text { inflection }\end{array}$ & $\begin{array}{l}\text { Obj-relative } \\
\text { clause }\end{array}$ & $\begin{array}{l}\text { The children liked the chocolates } \\
\text { that they bought. }\end{array}$ & $\begin{array}{l}\text { The children like to eat } \\
\text { chocolates. }\end{array}$ \\
\hline $\begin{array}{l}\text { Omission of copula- } \\
\mathrm{BE}\end{array}$ & $\begin{array}{l}\text { Short-actional } \\
\text { passive }\end{array}$ & $\begin{array}{l}\text { She was stopped at the big, red } \\
\text { lights. }\end{array}$ & $\begin{array}{l}\text { She stop }{ }^{1} \text { at the big, red } \\
\text { lights. }\end{array}$ \\
\hline $\begin{array}{l}\text { Omission of } \\
\text { auxiliary did }\end{array}$ & Wh-question & $\begin{array}{l}\text { Who did the monkey hit at the } \\
\text { zoo? }\end{array}$ & $\begin{array}{l}\text { Who hit the monkey at the } \\
\text { zoo? }\end{array}$ \\
\hline $\begin{array}{l}\text { Omission of Prep } \\
\text { head in PrepP } \\
\text { adjunct direction }\end{array}$ & $\begin{array}{l}\text { Short-actional } \\
\text { passive }\end{array}$ & $\begin{array}{l}\text { The children were taken to the } \\
\text { office. }\end{array}$ & $\begin{array}{l}\text { *The children were taken } \\
\text { office. }\end{array}$ \\
\hline
\end{tabular}

${ }^{1}$ This error is ignored for the omission of copula-BE error type, but it is taken into account for the omission of -ed inflection error type. 
Table 10

Examples of Malay sentence repetition scored based on grammaticality

\begin{tabular}{|c|c|c|c|}
\hline Morphological error & Sentence type & Target sentence & $\begin{array}{l}\text { Participants' } \\
\text { responses }\end{array}$ \\
\hline $\begin{array}{l}\text { Omission of relative marker } \\
\text { yang }\end{array}$ & $\begin{array}{l}\text { Sub-relative } \\
\text { clause }\end{array}$ & $\begin{array}{l}\text { a) Lukisan yang manakah kakak } \\
\text { lukis di bilik darjah? } \\
\text { (Translation: Which drawing did } \\
\text { the sister draw in the classroom?) }\end{array}$ & $\begin{array}{l}\text { *Lukisan manakah } \\
\text { kakak lukis di bilik } \\
\text { darjah? }\end{array}$ \\
\hline $\begin{array}{l}\text { Substitution of di-passive to } \\
\text { kena passive } \\
\text { substitution of preposition } \\
\text { oleh to dengan }\end{array}$ & Passive & $\begin{array}{l}\text { b) Kucing Ali dilanggar oleh } \\
\text { kereta semalam. } \\
\text { (Translation: Ali's cat was hit by } \\
\text { a car yesterday.) }\end{array}$ & $\begin{array}{l}\text { Kucing Ali kena } \\
\text { langgar dengan } \\
\text { kereta semalam. }\end{array}$ \\
\hline
\end{tabular}

*= ungrammatical

Table 11

Frequently substituted and added content words in the bilingual SR

\begin{tabular}{|c|c|c|c|c|}
\hline & \multicolumn{2}{|l|}{ Malay SR } & \multicolumn{2}{|l|}{ English SR } \\
\hline & Target word & Substitution/ Addition & Target word & Substitution/ Addition \\
\hline \multirow[t]{3}{*}{ Noun } & $\begin{array}{l}\text { biri-biri } \\
\text { (sheep) }\end{array}$ & $\begin{array}{l}\text { kambing } \\
\text { (goat) }\end{array}$ & homework & book \\
\hline & $\begin{array}{l}\text { gunung } \\
\text { (mountain) }\end{array}$ & $\begin{array}{l}\text { bukit } \\
\text { (hill) }\end{array}$ & student & children \\
\hline & & & mango & apple \\
\hline \multirow[t]{3}{*}{ Verb } & $\begin{array}{l}\text { bersarapan pagi } \\
\text { (have breakfast) }\end{array}$ & $\begin{array}{l}\text { makan } \\
\text { (eat) }\end{array}$ & baked & make, eat \\
\hline & $\begin{array}{l}\text { siapkan } \\
\text { (finish) }\end{array}$ & $\begin{array}{l}\text { buat } \\
\text { (do) }\end{array}$ & liked & loved, love \\
\hline & $\begin{array}{l}\text { bercita-cita } \\
\text { (aim) }\end{array}$ & $\begin{array}{l}\text { nak } \\
\text { (want to) }\end{array}$ & bought & got, brought \\
\hline Aspect & sedang (is, still) & $\begin{array}{l}\text { sudah (already), tengah } \\
\text { (still) }\end{array}$ & - & - \\
\hline Adverbs & $\begin{array}{l}\text { kelmarin } \\
\text { (the day before } \\
\text { yesterday) }\end{array}$ & $\begin{array}{l}\text { semalam } \\
\text { (yesterday) }\end{array}$ & - & - \\
\hline
\end{tabular}

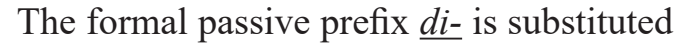
by the colloquial passive kena (get).

Additionally, substitutions made reflected the higher proficiency of the participants in Malay compared to English as presented in Table 11. The noun substitutions in English were in the form of hyponyms (broader meaning) compared to hypernyms (specific meaning) in Malay.
The verb substitutions in Malay were more accurate in meaning compared to verb substitutions in English SR.

\section{DISCUSSION}

An analysis of the effects of bilingualism and age on quantitative scoring of SR tasks was made possible by categorising the children into different age groups. Firstly, 
the significant differences between all age groups in both SR tasks based on the overall accuracy scores suggested that age is an important factor in the successful repetition of sentences as an increase in age suggests an increase in the cognitive, processing abilities and memory capacity (Pineo, 2014). The trajectory of syntactical development across all age groups demonstrated high developmental sensitivities (Conti-Ramsden et al., 2001; Marinis \& Armon-Lotem, 2015; Thordardottir et al., 2011). Secondly, the children performed significantly more accurate in L1 than L2. Regardless of age, all bilingual children performed similarly based on accuracy - higher SR accuracy in their L1 than L2. This result matched with general expectations that SR performance in L1 would be better than L2. The children only learn English formally when they are enrolled in preschools, generally around the age of 4. They use Malay at home and are generally more exposed to Malay in the first three years of life.

Even though English is a strong L2 in Malaysia (Thirusanku \& Md Yunus, 2014), its bilingual situation is never quite the same as in the West. Unlike Malaysia, the bilingual individuals in the West often come from the marginalized group who are immersed in the monolingual English environment. Learning L2 in the L1 environment (Malay being the dominant language) may restrict the ESL learners to get real life L2 exposure and hence may impede their L2 learning. This finding supports the notion that the wider language experience and exposure in their mother tongue accumulated through time make better language knowledge as can be seen in the proficiency in grammar and semantic information in L1 compared to L2 (Al-Zoubi, 2018).

In addition, the overall accuracy and grammaticality measure was positively correlated with each other. Our results corroborate the results from other studies which showed that overall language acquisition in monolinguals, as well as bilinguals (a), is strongly affected by the amount of language exposure a child gets, which then could be equated based on age factor, and (b) is often seen in the development of vocabulary and grammar (Thordardottir, 2011, 2014). Nevertheless, there seemed to be no interaction between sentence type and accuracy. This is because, in contrast to grammaticality measure, the procedure in giving scores for sentence type is less rigid. The child will be given a point for grammaticality even if the sentence type is wrong, for example:

Target sentence : Who did the monkey hit at the zoo? (object question)

Response : Who hit the monkey at the zoo?(subject question)

In the above sentence, children responded by making an error on the thematic role assignments partly due to the omission of auxiliary 'did' and movement of the $w h$-word NP. The theta role of $w h$-NP object in the target sentence was changed to $w h$-NP subject position in the child's repetition, hence falsely making this $w h$-NP as the Agent, instead of the 'monkey' that now appears to look like a Patient, which 
thus led to a change in wh-movement type sentence and an error in meaning. Note that, even though the response was not correct, the sentence was grammatical according to the structure of $w h$-subject type sentence; hence, the children scored 1 for grammaticality but 0 for sentence type and accuracy. This allowance was given to the children in the study as the error of assigning a Subject to an Object in wh-sentence is typical among children (Philip et al., 2002).

An error analysis was conducted to explore the idiosyncrasies of the morphosyntactic abilities of the children in this study. The most notable error was the omission error. Younger children with an emerging vocabulary would make more omission errors compared to the older children who have bigger vocabulary size due to more inputs and exposure from their own learning. Likewise, it appears that the lack of knowledge of function words would limit the children's options in the repetition (Komeili \& Marshall, 2013). In substitutions, children also showed specific abilities to substitute open-class content words. As children could not repeat the word prompts, they would rely on their knowledge of words and its semantic domains and used words which were either closer or further away from the word targeted depending on their level of proficiency in the language.

A higher language proficiency level would have participants use hyponyms (specific meaning) equivalents and a weaker language proficiency level would produce equivalents which are hypernyms (broader meaning) and further from the meaning of the targeted word. In Malay SR, children tended to use hyponyms for substitution of nouns compared to English where children tended to use hypernyms (refer Table 11 for more examples). The verb substitutions in English tended to be inaccurate and at times totally wrong compared to verb substitutions in Malay SR which were closer in meaning to the original verb. Our findings thus hypothesised that the higher number of content words known to children, the better it would facilitate them in either their substitution or addition strategy (Long, 1993). It is interesting to note that, regardless of the word substituted, the new word is found to have the same semantic domain as the original word. In addition, their choice of words reflects more of the colloquial variety, and this is expected since the participants were mostly exposed to their colloquial varieties of each language in their home environments. This also suggests that their vocabulary knowledge is shaped around high-frequency lexical items which are used in their spoken language daily.

The omission rate of function words was found to be higher compared to content words, indicating the nature of functions words which are difficult to acquire. Functional words carry grammatical meaning and are thus difficult to learn (Tomasello, 2002). Omission of English morphemes such as past tense inflection -ed, copula-BE, and auxiliary verb 'did' as shown in Responses 1 and 2 of Table 9 serves as evidence that inflections are harder to produce among Malay bilingual children because Malay does not inflect the verb and has no equivalent of the auxiliary or dummy DO. Malay has different manifestations for 
tenses compared to English (Razak et al., 2018). While English inflects the verbs for tenses, Malay uses lexical items such as adverbial of time or aspect to mark tense. In the context of L2 acquisition in Malaysia, the absence of inflection and different morphological structures between Malay and English, including -s, -es markers for plurality, and reflexive pronouns are some of the difficult morphological aspects faced by Malaysian students in learning L2 (English; Jalaluddin et al., 2008; Mat Awal et al., 2007). Another function word which is difficult to acquire is preposition. Response 3 in Table 9, *The children were taken office, is considered ungrammatical due to the omission of the preposition 'to' which is the head of the prepositional phrase. Without the presence of this head, the PrepP structure is thus rendered invalid and ungrammatical.

The rate of omission for the (a) relative marker 'that' (English) and 'yang' (Malay), (b) preposition 'by' (English) and 'oleh'

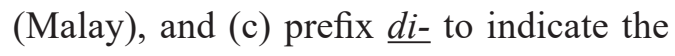
passive voice in Malay was found to be high. These errors were not uncommon as such omissions are reflective of colloquial Malay or English spoken in Malaysia. In the colloquial Malay and English varieties, the optional relative pronoun marker ' $y a n g /$ that' is often absent especially when the relative pronoun is the object of the verb, for example,

Target sentence: Mommy baked the cake that we like.

Response: Mommy baked the cake we like.
In Malay SR, the relative marker 'yang' is also omitted (refer to Response 1 of Table $10 *$ Lukisan manakah kakak lukis di bilik darjah? instead of the target response Lukisan yang manakah kakak lukis di bilik darjah?). Children omitted the relative marker 'yang' which resulted in an incomplete relative clause structure. Even though ' $y$ ang/that' is omitted, the meaning is manifested covertly in context. In Standard Malay, the RC marker 'yang' is obligatory. This resonates with Aman (2007)'s study which had children in her study produced relative clauses without 'yang' and the unmoved in-situ wh-questions based on Colloquial Malay. This is also supported by Abu Bakar et al. (2016) who studied the comprehension and production of relative clauses among two groups of Malay children -aged 4-6 years old and 7-9 years old - and found that preschool children had limited abilities with RC structures and had instead relied on simplification and substitution strategies. The RC structures were also not fully acquired by the older children in that they could produce subject relative clauses but not object relative clauses (ORC). The acquisition of $\mathrm{RC}$ seemed to continue into the later part of the primary school years. Relative clauses seemed to be a structure which was acquired later due to their complexity. It is a feature of formal Malay variety which children are exposed to only when they start schooling.

Passives seemed to be difficult to acquire too. Among the errors of derived verb forms such as prefixes meN- and beR-, the highest affixed error was the 
prefix $d i$ - in passives. In Malay, the $d i+$ base verb form is taught formally and is mostly used in formal situations such as academic settings, newspapers, books, and government correspondences. The bilingual children, however, showed a preference of using the adversative 'kena' (get) passive form, which is far more common in Colloquial Malay (Abu Bakar, 2017; Chung, 2005). One reason could be that the formal $d i$-involves a non-canonical word order while the kena passive retains the canonical SVO order, thus, making it easier to repeat. It is interesting to note that children with greater exposure (the older children in this study) found passive

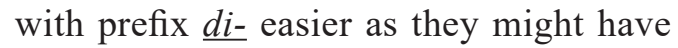
been exposed to it longer than the younger children and might have learnt it as part of their learning in school (Abu Bakar, 2017). Generally, children also tended to use the agentless passive sentence, and, even if it is mentioned, it is usually not preceded by the preposition 'oleh /by' as shown in the example below:

Target sentence: Mainan itu akan dibeli oleh ayah di bandar.

Toy-affix the will PASS-buy by father at town

'The toy will be bought by father in town.'

Response : Mainan itu dibeli ayah di bandar. (omission of 'oleh/by')

In addition, the older age group children were also more persistent in substituting oleh/by with dengan/with (refer Response
2 in Table 10: Kucing Ali kena langgar dengan kereta semalam). In this example, the children chose to substitute 'oleh/by' with the multi-purpose preposition form 'dengan/with' as their strategy. 'Dengan/ with' in Colloquial Malay carries multiple meanings: accompaniment, instrumental, and conjunction (dan/and) whereas, in Standard Malay, it has only one meaning that is accompaniment. Furthermore, it is not grammatical to use dengan/with with passives as the meaning of agent can only be conveyed by the preposition oleh/by. Preposition such as dengan seems to have a relational meaning for different purposes, and this may pose difficulties to young language learners. Thus, for Malay children who are first exposed to Colloquial Malay and then subsequently learn formal Malay, they will need to learn to transition from Colloquial Malay to formal Malay or viceversa whenever appropriate.

With regards to error patterns at the syntactic level, this study focused on children's use of word order cues to comprehend both canonical and noncanonical order. The canonical word order in both Malay and English is subjectverb-object (SVO). The word order is not difficult for typically developing children as children can process them linearly (Montgomery \& Evans, 2009; Montgomery et al., 2017). However, this is not the case with younger children and children whose language is impaired. Complex structures such as passives, object-relative clause, and embedded $w h$ - questions are, however, non-canonical in nature. They exhibit non- 
SVO word order and thus are difficult to comprehend than canonical structures (Abu Bakar, 2017). According to Montgomery et al. (2017), although the surface forms of passives, object-relative, and objectquestions are different, children must come to realize that (a) NP1 appears in the subject position but it functions as a patient and (b) NP2 occupies the object position but it functions as an agent. These new thematic role assignments entail movement that is hard to be perceived by young language learners. A similar difficulty is shown in the example below:

Target sentence : The homework that teacher gave me was easy. (Subject RC)

Response : Iget the homework. It's easy. (2 simple sentences)

In the case of movement-derived structures such as the example above, children might have treated the movement operation as an option. This usually costs them to simplify complex sentences; in this case, the sentence with a complex NP subject which embeds a RC is split into two simple sentences. This demonstrates the inability of the children to repeat embedded complex noun phrase structure sentence. Another difficult structure is the ORC (as shown as Response 3 in Table 9) in which participants repeated the targeted ObjectWh NP as a Subject-Wh NP with the latter being the easier form. The children's poor performances in repeating non-canonical structures and movement-derived structures show no significant improvement with age (as similar patterns of errors were also distributed among older children), indicating that these structures are structures which are acquired much later.

\section{CONCLUSION}

The current paper investigated sentence repetition among Malay bilingual preschool children using Malay-English and found that accuracy measures could detect the morphosyntactic developmental trajectories of the sequential bilingual population. Older children appeared to be more successful than younger children, and they were generally more accurate in their L1 morphosyntactic performance than L2. Additionally, omission on both content and function words was found to be prominent among all age groups. It was also found that substitution and addition errors are unique only to children of older age groups, indicating limited knowledge on function words among younger children. Given the heterogeneity of the bilingual communities in Malaysia, i.e., the types of schools and the socioeconomic backgrounds, it would be interesting to investigate future research exploring other grouping of languages such as English-Mandarin-Malay among Chinese bilingual children. This would bring up further intricacies of the nature of bi/multilingualism in Malaysia. Findings from this study could be used as a basis for such research using SR task, looking at morphosyntactic abilities. It is also highly recommended that future research, with regards to the paradigm of this study, uses data from atypical population to generate differential diagnosis. 


\section{ACKNOWLEDGEMENT}

We are grateful to Bi-SLI working group COST Action IS0804 Language Impairment in a Multilingual Society: Language Patterns and the Road to Assessment for the template of SR task and Theodoros Marinis from University of Konstanz for his assistance in scoring guidelines. Finally, our appreciation goes to the children participants who took part in this study, their parents, and teachers.

\section{REFERENCES}

Abu Bakar, N. (2017). Kemahiran sintaksis dalam kalangan kanak- kanak Melayu dengan kecelaruan bahasa spesifik [The syntactic abilities of Malay children with Specific Language Impairment (SLI); Unpublished doctoral dissertation]. Universiti Kebangsaan Malaysia.

Abu Bakar, N., Razak, R. A., \& Lim, H. W. (2016). Pemerolehan klausa relative dalam kalangan kanak-kanak Melayu: Satu kajian awal [The acquisition of relative clauses among Malay children: A preliminary study]. GEMA: Online Journal of Language Studies, 16(3). 145-165. http://doi.org/10.17576/gema-2016-1603-10

Al-Zoubi, S. M. (2018). The impact of exposure to English language on language acquisition. Journal of Applied Linguistics and Language Research, 5(4), 151-162.

Aman, N. (2007). The acquisition of Malay whquestions. Lincom Europa.

Brojde, C. L., Ahmed, S., \& Colunga, E. (2012). Bilingual and monolingual children attend to different cues when learning new words. Frontiers in Psychology, 3, 155. http://doi. org/10.3389/fpsyg.2012.00155

Chung, S. F. (2005). Kena as a third type of the Malay passive. Oceanic Linguistics, 44, 194-214. http:// doi.org/10.1353/ol.2005.0017
Conti-Ramsden, G., Botting, N., \& Faragher, B. (2001). Psycholinguistic markers for specific language impairment. Journal of Child Psychology and Psychiatry, 42, 741-748. http:// doi.org/10.1111/1469-7610.00770

Gatt, D., \& Dodd, B. (2019). Preschoolers' lexical skills in two majority languages: Is there any evidence for the onset of sequential bilingualism? International Journal of Bilingualism, 24(2). https://doi.org/10.1177/1367006919826408

Hoff, E., \& Core, C. (2013). Input and language development in bilingually developing children. Seminars in Speech and Language, 34(4), 215226. http://doi.org/10.1055/s-0033-1353448

Hoff, E., Core, C., Place, S., Rumiche, R., Senor, M., \& Parra, M. (2012). Dual language exposure and early bilingual development. Journal of Child Language, 39, 1-27. http://doi.org/10.1017/ S0305000910000759

Jalaluddin, N. H., Mat Awal, N., \& Abu Bakar, K. (2008). The mastery of English language among lower secondary school students in Malaysia: A linguistic analysis. European Journal of Social Sciences, 7(2), 106-119.

Kaltsa, M., Prentza A., \& Tsimpli, I. M. (2019). Input and literacy effects in simultaneous and sequential bilinguals: The performance of Albanian-Greek-speaking children in sentence repetition. International Journal of Bilingualism, 24(2), 159-183. http://doi. org/10.1177/1367006918819867

Kan, P. F., \& Kohnert, K. (2005). Preschoolers learning Hmong and English: Lexical semantic skills in L1 and L2. Journal of Speech Language and Hearing Research, 48(2), 372-83. http://doi. org/10.1044/1092-4388(2005/026)

Kohnert, K. (2010). Bilingual children with primary language impairment: Issues, evidence and implications for clinical actions. Journal of Communication Disorder, 43(6), 456-473. http:// doi.org/10.1016/j.jcomdis.2010.02.002 
Komeili, M., \& Marshall, C. R. (2013). Sentence repetition as a measure of morphosyntax in monolingual and bilingual children. Clinical Linguistics \& Phonetics, 27(2), 152-162. http:// doi.org/10.3109/02699206.2012.751625

Leclercq, A. L., Quémart. P., Magis, D., \& Maillart, C. (2014). The sentence repetition task: A powerful diagnostic tool for French children with specific language impairment. Research in Developmental Disabilities, 35, 3423-3430. https://doi.org/10.1016/j.ridd.2014.08.026

Long, J. (1993). Pemerolehan imbuhan pada peringkat prasekolah dan implikasinya terhadap pendidikan bahasa [Acquisition of affixation at the preschool level and its implications to language education]. Dewan Bahasa dan Pustaka.

Marinis, T., \& Armon-Lotem, S. (2015). Sentence Repetition. In S. Armon-Lotem, J. D. Jong, \& N. Meir (Eds.), Methods for assessing multilingual children: Disentangling bilingualism from Language Impairment ( $\mathrm{p}$. 95-124). Multilingual Matters. https://doi. org/10.21832/9781783093137-007

Marinis, T., Chiat, S., \& Armon-Lotem, S. (2012). Multi-lingual sentence imitation task (MultiSIT)-30 sentences. University of Reading.

Mat Awal, N., Jalaluddin, N. H., Hamid, N. Z. A., \& Abu Bakar, K. (2007, June 14-16). First language influence on second language performance: A study of common English grammatical errors among rural secondary school students [Conference presentation]. The Second Biennial International Conference on Teaching and Learning of English in Asia, Langkawi, Malaysia.

Meir, N., Walters, J., \& Armon-Lotem, S. (2015). Disentangling SLI and bilingualism using sentence repetition tasks: The impact of L1 and L2 properties. International Journal of Bilingualism, 20(4), 421-452. https://doi. org/10.1177/1367006915609240
Montgomery, J., \& Evans, J. L. (2009). Complex sentence comprehension and working memory in children with specific language impairment. Journal of Speech, Language, and Hearing Research, 52(2), 269-288. https://doi. org/10.1044/1092-4388(2008/07-0116)

Montgomery, J., Gillam, R. B., Evans, J. L., \& Sergeev, A. V. (2017). "Whatdunit?” sentence comprehension abilities of children with SLI: Sensitivity to word order in canonical and noncanonical structures. Journal of Speech Language and Hearing Research, 60(9), 2603. https://doi.org/10.1044/2017_jslhr-1-17-0025

Montgomery, J., Magimairaj, B., \& Finney, M. (2010). Working memory and specific language impairment: An update on the relation and perspectives on assessment and treatment. American Journal of Speech-language Pathology / American Speech-Language Hearing Association, 19, 78-94. https://doi. org/10.1044/1058-0360(2009/09-0028)

Montrul, S. (2009). Reexamining the fundamental difference hypothesis: What can early bilinguals tell us? Studies in Second Language Acquisition, 31(2), 225-257. https://doi.org/10.1017/ S0272263109090299

Ooi, C. C.-W., \& Wong, A. M.-Y. (2012). Assessing bilingual Chinese-English young children in Malaysia using language sample measures. International Journal of Speech Language Pathology, 14(6), 499-508. https://doi.org/10.3 109/17549507.2012.712159

Orlovska, M., \& Rascevska, M. (2014). Construction and psychometric properties of Sentence Repetition Test (SRT) for Latvian primary school children. Journal of Educational and Social Research, 4(4), 104.

Paradis, J. (2009). Second language acquisition in childhood. In E. Hoff \& M. Shatz (Eds.), Handbook of Language Development (pp. 387-406). Blackwell. https://doi. org/10.1002/9780470757833.ch19 
Paradis, J. (2010). The interface between bilingual development and specific language impairment. Applied Psycholinguistics, 31, 3-28. https://doi. org/10.1017/S0142716409990373

Philip, W. C. H., Coopmans, P., Atteveldt, W., \& Van Der Meer, M. (2002). Subject-object assymmetry in child comprehension of wh-questions. In A. H.-J. Do, L. Dominguez \& A. Johansen (Eds.), Proceedings of the 25th Boston University Conference on Language Development (pp. 587598). Cascadilla.

Pineo, R. (2014). Sentence repetition performance in bilingual children with SLI compared to age and language-matched peers [Master's dissertation, McGill University, Montreal]. eScholarship McGill.

Polišenská, K., Chiat, S., \& Roy, P. (2015). Sentence repetition: What does the task measure? International Journal of Language and Communication Disorders, 50(1), 106-118. https://doi.org/10.1111/1460-6984.12126

Razak, R. A., Neelagandan, A., Md Yusof, N., Lim, H. W., Ahmad, K., \& Madison, C. (2018). The validation of the Malay Preschool Language Assessment Tool (MPLAT): The screening and diagnostic versions. Malaysian Journal of Public Health Medicine, Special Issue, 1, 191-115.

Riches, N. G. (2012). Sentence repetition in children with specific language impairment: An investigation of underlying mechanisms. International Journal of Language \& Communication Disorders, 47(5), 499-510. https://doi.org/10.1111/j.14606984.2012.00158.x.

Riches, N. G., Loucas, T., Baird, G., Charman, T., \& Simonoff, E. (2010). Sentence repetition in adolescents with specific language impairment and autism: An investigation of complex syntax. International Journal of Language \& Communication Disorders, 45(1), 47-60. https:// doi.org/10.3109/13682820802647676
Seeff-Gabriel, B., Chiat, S., \& Dodd, B. (2010). Sentence imitation as a tool in identifying expressive morphosyntactic difficulties in children with severe speech difficulties. International Journal of Language \& Communication Disorder, 45(6), 691-702. https://doi.org/10.3109/13682820903509432

Stokes, S. F., Wong, A. M.-Y., Fletcher, P., \& Leonard, L. B. (2006). Nonword repetition and sentence repetition as clinical markers of specific language impairment: The case of Cantonese. Journal of Speech Language and Hearing Research, 49(2), 219. https://doi.org/10.1044/10924388(2006/019)

Theodorou, E., Kambanaros, M., \& Grohmann, K. K. (2017). Sentence repetition as a tool for screening morphosyntactic abilities of bilectal children with SLI. Frontiers in Psychology, 8(2104). https://doi.org/10.3389/fpsyg.2017.02104

Thirusanku, J., \& Md Yunus, M. (2014). Status of English in Malaysia. Asian Social Science, 10(14). https://doi.org/10.5539/ass.v10n14p254

Thordardottir, E. (2011). The relationship between bilingual exposure and vocabulary development. International Journal of Bilingualism, 15(4), 426445. https://doi.org/10.1177/1367006911403202

Thordardottir, E. (2014). The typical development of simultaneous bilinguals: Vocabulary, morphosyntax and language processing in two age groups of Montreal preschoolers. In T. Grüter, \& J. Paradis (Eds.), Input and experience in bilingual development (pp. 141-160). John Benjamins. https://doi.org/10.1075/tilar.13.08tho

Thordardottir, E., \& Brandeker, M. (2013). The effect of bilingual exposure versus language impairment on nonword repetition and sentence imitation scores. Journal of Communication Disorders, 46(1), 1-16. https://doi.org/10.1016/j. jcomdis.2012.08.002 
Thordardottir, E., Kehayia, E., Mazer, B., Lessard, N., Majnemer, A., Sutton, A., Trudeau, N., \& Chilingaryan, G. (2011). Sensitivity and specificity of French language and processing measures for the identification of primary language impairment at age 5. Journal of Speech Language and Hearing Research, 54, 580-597. https://doi.org/10.1044/1092-4388(2010/090196)

Tomasello, M. (2002). The emergence of grammar in early child language. In T. Givón \& B. Malle (Eds.), The evolution of language out of prelanguage (pp. 309-328). Benjamins. https:// doi.org/10.1075/ts1.53.17tom

Tomblin, J. B., Records, N. L., Buckwalter, P., Zhang, X., Smith, E., \& O'Brien, M. (1997). Prevalence of specific language impairment in kindergarten children. Journal of Speech, Language and Hearing Research, 40(6), 1245-1260. https:// doi.org/10.1044/jslhr.4006.1245
Vicari, S., Caselli, M. C., Gagliardi, C., Tonucci, F., \& Volterra, V. (2002). Language acquisition in special populations: A comparison between Down and Williams syndromes. Neuropsychologia, 40(13), 2461-2670. https://doi.org/10.1016/ S0028-3932(02)00083-0

Willis, C., \& Gathercole, S. (2001). Phonological shortterm memory contributions to sentence processing in young children. Memory, 9, 349-363. https:// doi.org/10.1080/09658210143000155

Woon, C. P. (2012). Use of nonword and sentence repetition tasks among Mandarin-English bilingual children in Malaysia [Unpublished Master's thesis]. Universiti Putra Malaysia.

Woon, C. P., Ngee T. Y., Lim, H. W., \& Bee. E. W. (2014). Measuring grammatical development in bilingual Mandarin-English speaking children with a sentence repetition task. Journal of Education and Learning, 3(3). https://doi. org/10.5539/jel.v3n3p144 